OPEN ACCESS

Edited by:

Yimin Cai,

Japan International Research Center for Agricultural Sciences (JIRCAS),

Japan

Reviewed by:

Qing Zhang,

South China Agricultural University,

China

Mao Li,

Chinese Academy of Tropical

Agricultural Sciences, China

*Correspondence:

Ping LI

lpyzm@sina.cn

Specialty section:

This article was submitted to

Microbiotechnology,

a section of the journal

Frontiers in Microbiology

Received: 29 March 2021 Accepted: 19 April 2021

Published: 07 July 2021

Citation:

Guo L, Lu Y, Li P, Chen L, Gou W and Zhang C (2021) Effects of Delayed Harvest and Additives on Fermentation Quality and Bacterial Community of Corn Stalk Silage. Front. Microbiol. 12:687481. doi: 10.3389/fmicb.2021.687481

\section{Effects of Delayed Harvest and Additives on Fermentation Quality and Bacterial Community of Corn Stalk Silage}

\author{
Linna Guo ${ }^{1,2}$, Yongxiang $L u^{3}$, Ping $L^{1,3 *}{ }^{1,}$ Liangyin Chen ${ }^{1}$, Wenlong Gou ${ }^{3}$ and \\ Changbin Zhang ${ }^{3}$ \\ ${ }^{1}$ College of Animal Science, Guizhou University, Guiyang, China, ${ }^{2}$ College of Grassland Science and Technology, China \\ Agricultural University, Beijing, China, ${ }^{3}$ Sichuan Academy of Grassland Sciences, Chengdu, China
}

This study aimed to investigate the effects of delayed harvest and additives on the fermentation quality and bacterial community of corn stalk silage in South China. The corn stalks after ear harvest at the 0 day (D0), 7 days (D7), and 15 days (D15) were used to produce small-bale silages. The silages at each harvest time were treated without (control, CK) or with Lactobacillus plantarum (LP) and sodium benzoate (BF). The results showed that delayed harvest increased $\mathrm{pH}$ and acetic acid content and reduced lactic acid content in corn stalk silage $(p<0.05)$. Compared with $C K$, the additives decreased the contents of butyric acid and ammonia nitrogen $\left(\mathrm{NH}_{3}-\mathrm{N} ; p<0.05\right)$. The silage treated with LP increased the content of lactic acid and decreased $\mathrm{pH}(p<0.05)$; the silage treated with BF decreased counts of coliform bacteria and yeasts and increased residual water soluble carbohydrates (WSC) content $(p<0.05)$. Single Molecule, Real-Time sequencing (SMRT) revealed that the abundance of $L$. plantarum increased, while the abundance of Lactobacillus brevis and Lactobacillus ginsenosidimutans decreased with the delayed harvest. Additives influenced the bacterial community structure of corn stalk silage, revealed by enhanced bacterial diversity on D0 and reduced on D7 ( $p<0.05)$. Our research indicated that delayed harvest could exert a positive effect on acetic acid production, and additives could inhibit the butyric acid fermentation and protein degradation of corn stalk silage by shifting bacterial community composition.

Keywords: corn stalk silage, delayed harvest, sodium benzoate, Lactobacillus plantarum, bacterial community

\section{INTRODUCTION}

Corn (Zea mays) is an important grain-forage crop. In recent years, the intercropping technology has been widely applied to produce abundant corn stalk in South China. However, most corn stalks with a high content of structural carbohydrates (50-70\%) are discarded, which is wasteful and creates environmental atmospheric pollution (Li et al., 2015; Zhang et al., 2020a). Furthermore, with the increase of the demand for animal products, feed shortage hinders the development of the animal husbandry. Nowadays, high stay-green corn has been developed, which is characterized by a high chlorophyll concentration in the leaves at "stalk" maturity, with high 
stalk and leaf moisture concentrations (Thomas and Smart, 1993; Bekavac et al., 1998). Importantly, moisture and crude protein (CP) concentration are relatively high in stay-green corn stalks. It is cost-effective to convert stay-green corn stalk into ruminal feed. However, how to effectively utilize corn stalks in the animal production system is a concerned issue.

Ensiling has been regarded as an effective method for preserving fresh forage due to its long storage duration, good palatability, and high nutrition. Traditional corn is usually harvested at milk ripe or wax stages for producing high-quality silage (Zhang et al., 2010; Wang et al., 2018a). In practice, delayed harvest reduced feed value of corn stalk (Cai et al., 2020). To optimize the storage of corn stalks, Lactobacillus plantarum (LP), a homofermentative strain of lactic acid bacteria (LAB), has been used as additive to enhance the fermentation quality of silage ( $\mathrm{Ni}$ et al., 2017a; Xu et al., 2018; Guo et al., 2020a,b). Recently, sodium benzoate (BF) has been mainly applied as a microbial growth controller in silage production (Zhang et al., 2020b), which could inhibit the growth of harmful bacteria and fungi, thus improve the fermentation quality and aerobic stability of silages (Kleinschmit et al., 2005; Da Silva et al., 2015; Muck et al., 2018). However, there are only a few literatures on the efficiency of both additives (LP and BF) in producing silage of stay-green corn stalks, especially during delayed harvest in the southeast of Qinghai Tibetan Plateau.

In recent years, next-generation sequencing (NGS) technology has made the microbiota classification accurate to genus and has been increasingly utilized to analyze microbial population in silage (Ni et al., 2017a; Wang et al., 2018b; Keshri et al., 2019). However, it restricts the sensitivity and accuracy of classification. Nowadays, Single Molecule, Real-Time sequencing (SMRT) is used for high taxonomic resolution at the species level and has been employed in silages of corn, Italian ryegrass, and paper mulberry (Xu et al., 2018; Yan et al., 2019; Du et al., 2021). Nevertheless, there are few reports investigating the bacterial community based on species level and the mechanism underlying the response to additives of delayed harvest corn stalk silage.

In this study, we supposed that delayed harvest could influence the ensilability of corn stalk, and the use of additives during ensiling were beneficial to fermentation quality of the silage mainly by shifting bacterial community compositions. Therefore, we aimed to investigate the effects of delayed harvest and additives on the bacterial community and fermentation quality of corn stalk silage.

\section{MATERIALS AND METHODS}

\section{Silage Preparation}

Eighteen field plots were designed to cultivate stay-green corns (Tieyan 53, Beijing Hejiayun Agriculture Sci-Tech Co., Ltd.) on the experimental base of Sichuan Academy of Grassland Sciences, Aba, China (N 31 $51^{\prime}-33^{\circ} 33^{\prime}$, E 101 $\left.51^{\circ}-103^{\circ} 22^{\prime}\right)$. Stay-green corn stalks were cut after 0,7 , or 15 days of ear harvest (six plots for each delayed harvest; ear provided for human diet; and assessed at D0, D7, and D15, respectively), and chopped to a length of $0.5-1.0 \mathrm{~cm}$. In each plot, the chopped stalks were randomly divided into three equal parts for treatment with additive. The ensiling materials were treated with no additive as control (CK), with LP [a recommended application rate of $10^{5} \mathrm{cfu} / \mathrm{g}$ fresh matter (FM), isolated from corn silage in our laboratory and was reported from Chen et al., 2020a,b] or with BF (a suggested application rate of $1.0 \mathrm{~g} / \mathrm{kg}$ FM, provided from Prodpad Technology Co., Ltd.). Each bale (about one cubic meter) contained approximately $800 \mathrm{~kg}$ (FM) of corn stalks, and a total of 54 bales ( 3 delayed harvest $\times 3$ treatments $\times 6$ replicates) were produced using small baling system, with the density of about $580 \mathrm{~kg} / \mathrm{m}^{2}$ and the blank stretch film of four layers. All bales were stored at room temperature $\left(10-20^{\circ} \mathrm{C}\right)$ for 60 days, and then sampled for the analysis on chemical, microbial composition, fermentation parameter, and bacterial community.

\section{Chemical Analysis}

Each sample of $20 \mathrm{~g}$ was mixed with $180 \mathrm{ml}$ sterile water and a laboratory juicer for $1 \mathrm{~min}$, and then filtered through four layers of cheesecloth. The filtrate was subjected to centrifugation $\left(4,500 \times g, 15 \mathrm{~min}, 4^{\circ} \mathrm{C}\right)$. The supernatant was used to measure $\mathrm{pH}, \mathrm{NH}_{3}-\mathrm{N}$, and organic acid. The $\mathrm{pH}$ was determined by $\mathrm{pH}$ meter. $\mathrm{NH}_{3}-\mathrm{N}$ was determined by method of Broderick and Kang (1980). Lactic, acetic, propionic, and butyric acids were analyzed using high-performance liquid chromatography (Tian et al., 2017).

Each sample of $200 \mathrm{~g}$ was dried at $65^{\circ} \mathrm{C}$ for a constant weight to determine dry matter (DM) content, and then ground by a $0.20 \mathrm{~mm}$ sieve for the following analysis. CP was determined by the method of AOAC (1990). Both neutral detergent fiber (aNDF, neutral detergent fiber assayed with a heat stable amylase and expressed inclusive of residual ash) and acid detergent fiber (ADF) were determined using an Ankom 2000 fiber analyzer (Ankom Technology, Fairport, NY) by method of Van Soest et al. (1991). WSC was determined by the method of Murphy (1958).

\section{Microbial Analysis}

The microbial count of each sample was determined by the method of Cai et al. (1999), and described by Li et al. (2020). In brief, each sample of $10 \mathrm{~g}$ was mixed with $90 \mathrm{ml}$ sterile saline, shaken for $30 \mathrm{~min}$ and then filtered through sterile gauze. Serial dilutions were performed. The count of LAB was determined on MRS agar (CM188, Land Bridge Technology Co., Ltd., Beijing, China) and incubated at $30^{\circ} \mathrm{C}$ for $48-72 \mathrm{~h}$ under anaerobic conditions (Anaerobic box; TEHER Hard Anaerobox, ANX-1; Hirosawa Ltd., Tokyo, Japan). Aerobic bacteria were counted on nutrient agar (CM107, Land Bridge Technology Co., Ltd., Beijing, China) and inoculated at $28^{\circ} \mathrm{C}$ for 24-36 h under aerobic conditions. Coliform bacteria were counted on ECCA cheomogenic medium (RP0436, Guangzhou LES Biological Technology, Co. Ltd., Guangzhou China). Yeasts and molds were counted on malt extract agar with $1.5 \mathrm{mg} / \mathrm{L}$ Tetracycline (CM164, Land Bridge Technology Co., Ltd., Beijing, China) and incubated at $28^{\circ} \mathrm{C}$ for $48 \mathrm{~h}$. Yeasts were distinguished from molds through colony appearance and observation of cell morphology. 
Total genome DNA from each sample was extracted by CTAB method. DNA after purification was diluted to $1 \mathrm{ng} / \mathrm{ml}$ using sterile water. The full-length $16 \mathrm{~S}$ ribosomal RNA (rRNA) gene was amplified used specific primer (27F and 1541R) with the barcode (Yan et al., 2019). The PCR reaction was carried out by TransStart ${ }^{\circledR}$ FastPfu DNA Polymerase (TransGen Biotech). Triplicate amplifications from each sample were mixed for establish libraries. PCR products were mixed in equal density ratios and purified with QIAquick@Gel Extraction Kit (QIAGEN). Libraries were established using SMRTbellTMTemplate Prep Kit (PacBio) following manufacturer's recommendations, and then sequenced on the PacBio Sequel platform.

Raw sequences were initially processed through the PacBio SMRTportal. Sequences were filtered to produce reads without barcode and primer sequence. The reads were compared with the reference database using UCHIME algorithm ${ }^{1}$ to detect chimera sequences (Edgar et al., 2011), and then the chimera sequences were removed for obstaining clean reads (Haas et al., 2011). Sequences analysis was performed by Uparse software (Uparse v7.0.1001; Edgar, 2013). ${ }^{2}$ Sequences with the similarity $\geq 97 \%$ were distributed to the same operational taxonomic unit (OUT).

Following the OTU analysis, principal coordinates analysis (PCoA) was performed using R software (Version 2.15.3) based on the beta-diversity analysis. Representative sequence for each OTU was screened out for annotating taxonomic information in the SSUrRNA Database of Silva Database (Qiong et al., 2007; Christian et al., 2012). After the establishment of the phylogenetic relationship (Edgar, 2004), the number of observed species, richness index of abundance-based coverage estimator (ACE) and Chao 1, and diversity index of Shannon were calculated using QIIME software (Version1.9.1) and displayed with $\mathrm{R}$ software (Version 2.15.3). The heat map of spearman analysis was performed using a $\mathrm{R}$ based statistics tool.

\section{Statistical Analysis}

Before statistical analysis, microbial counts of each silage sample were estimated as $\log _{10} \mathrm{cfu} / \mathrm{g}$ of FM. Factorial analysis of variance was performed to evaluate the effects of delayed harvest $(\mathrm{D})$, additive $(\mathrm{A})$, and their interaction $(\mathrm{D} \times \mathrm{A})$ on the chemical composition, microbial population, and bacterial community indices of silage in the General Line Model of SPSS (SPSS 25.0 program, SPSS Inc., Chicago, Illinois, United States). There were significant differences only when the probability level was lower than $0.05(p<0.05)$.

\section{RESULTS AND DISCUSSION}

\section{Chemical and Microbial Compositions of Corn Stalks Prior to Ensiling}

Chemical and microbial compositions of stay-green corns prior to ensiling were shown in Table 1. Delayed harvest had significant effects on contents of DM, WSC, CP, aNDF, ADF,

${ }^{1}$ http://www.drive5.com/usearch/manual/uchime_algo.html ${ }^{2}$ http://drive5.com/uparse/ and counts of LAB, coliform bacteria, aerobic bacteria, and yeasts $(p<0.05)$. DM, aNDF, and ADF contents of corn stalks significantly increased with the harvest delayed $(p<0.05)$, which indicated that the lignification degree of corns could be deepened with delayed harvest. WSC and CP contents in this study significantly decreased from 8.88 to $7.29 \%$ DM and from 9.22 to $6.53 \% \mathrm{DM}$, respectively. There was also similar observation from Guo et al. (2019), which suggested a loss of nutrient in delayed harvest corn stalk. WSC is an important substance for the growth and propagation of epiphytic microorganisms, especially for LAB. In this study, the WSC content beyond 6\% DM was sufficient for the production of high-quality silage. However, relatively high counts $\left(10^{5}-10^{7} \mathrm{cfu} / \mathrm{g}\right.$ FM) of undesirable microorganisms (coliform bacteria, aerobic bacteria, and yeasts) on the plants were observed on corn stalks from D0 to D15. Although the count of epiphytic LAB on the plant of direct-cut stay-green corn (D0) was $10^{5} \mathrm{cfu} / \mathrm{g}$ $\mathrm{FM}$, which was enough for initiating lactic acid fermentation under anaerobic condition. The count decreased from D0 to D15 to $10^{4} \mathrm{cfu} / \mathrm{g} \mathrm{FM}$, which was insufficient for silage preservation (Cai et al., 1999). The above findings indicated that the delayed harvest could be harmful for the fermentation quality of corn stalk silage, and the unfavorable properties of stay-green corns for silage implied that it was necessary to add exogenous additives to enhance fermentation during ensiling.

\section{Chemical Composition of Corn Stalk Silage}

The chemical composition of corn stalk silages treated without (CK) or with LP and BF was shown in Table 2. Delayed harvest significantly affected all parameters of chemical composition $(p<0.001)$. Additives had significant effects on residual WSC, aNDF, and ADF contents $(p<0.05)$. Their interaction only had a significant effect on residual WSC and aNDF contents of silage $(p<0.05)$. DM, aNDF, and ADF contents of silage significantly increased with advancing maturity, which might due to the decrease of the moisture and the increase of the cell wall content in stem with advancing maturity (Yari et al., 2012; Sikora et al., 2019). The CP content of corn stalk silage gradually decreased $(p<0.001)$ from D0 to D15, which might due to the higher protein content in corn leaves than stems. Moreover, a high CP content was found in LP-treated silage numerically. The behind reason might be that proteolysis was inhibited by acid accumulation during ensiling (Chen et al., 2020b). During ensiling, some microbes, such as coliform bacteria, LAB, and yeasts, could produce energy with WSC (Kung et al., 2018; Queiroz et al., 2018). In this study, a high residual WSC content $(3.48-4.64 \%$ DM) was observed in BF-treated silages on D0 and D15 $(p<0.05)$. Similar reports were also found from Alli et al. (1985) and Da Silva et al. (2015), and that might because the antimicrobial capacity of $\mathrm{BF}$ could inhibit the growth of microbe, and then reduce their WSC metabolism. This confirmed that the treatment with LP and BF could enhance the preservation of silage nutrients although there was a loss of nutrients with the delayed harvest. 
TABLE 1 | Chemical and microbial compositions of corn stalks after 0 (D0), 7 (D7), and 15 (D15) days of ear harvest.

\begin{tabular}{|c|c|c|c|c|c|c|c|c|c|c|}
\hline \multirow{2}{*}{ Delayed harvest } & DM & WSC & CP & aNDF & ADF & $\begin{array}{l}\text { Lactic acid } \\
\text { bacteria }\end{array}$ & $\begin{array}{l}\text { Coliform } \\
\text { bacteria }\end{array}$ & $\begin{array}{c}\text { Aerobic } \\
\text { bacteria }\end{array}$ & Yeasts & Molds \\
\hline & $\%$ & \multicolumn{4}{|c|}{$\%$ DM } & \multicolumn{5}{|c|}{$\log _{10} c f u / g ~ F M$} \\
\hline DO & $25.31^{c}$ & $8.88^{a}$ & $9.22^{\mathrm{a}}$ & $50.41^{b}$ & $31.18^{b}$ & $5.35^{\mathrm{a}}$ & $6.50^{\mathrm{a}}$ & $7.48^{a}$ & $6.11^{b}$ & 3.52 \\
\hline D7 & $28.46^{b}$ & $8.15^{\mathrm{ab}}$ & $7.01^{\mathrm{b}}$ & $58.79^{a}$ & $32.19^{b}$ & $4.87^{b}$ & $5.23^{b}$ & $7.16^{\mathrm{a}}$ & $6.68^{a}$ & 3.44 \\
\hline D15 & $35.18^{a}$ & $7.29^{b}$ & $6.53^{c}$ & $61.48^{a}$ & $34.01^{\mathrm{a}}$ & $4.19^{c}$ & $5.76^{b}$ & $5.45^{b}$ & $6.82^{\mathrm{a}}$ & 3.69 \\
\hline SEM & 1.49 & 0.35 & 0.42 & 1.69 & 0.47 & 0.18 & 0.20 & 0.33 & 0.12 & 0.09 \\
\hline Significance ( $p$-value) & $<0.001$ & 0.044 & $<0.001$ & $<0.001$ & 0.007 & 0.001 & 0.003 & $<0.001$ & 0.006 & 0.658 \\
\hline
\end{tabular}

DM, dry matter; WSC, water soluble carbohydrates; CP, crude protein; ADF, acid detergent fiber; aNDF, neutral detergent fiber; FM, fresh matter; and SEM, standard of error mean. Different letters within a column are significantly different $(p<0.05)$

TABLE 2 | Chemical composition of corn stalk silages treated without (CK) or with Lactobacillus plantarum (LP) and sodium benzoate (BF).

\begin{tabular}{|c|c|c|c|c|c|c|}
\hline \multirow{2}{*}{$\begin{array}{l}\text { Delayed } \\
\text { harvest }\end{array}$} & \multirow[t]{2}{*}{ Additive } & \multirow{2}{*}{\begin{tabular}{|l} 
DM \\
$\%$
\end{tabular}} & \multirow[t]{2}{*}{$\begin{array}{l}\text { Residual } \\
\text { WSC }\end{array}$} & CP & \multirow[t]{2}{*}{ aNDF } & \multirow[t]{2}{*}{ ADF } \\
\hline & & & & $\%$ DM & & \\
\hline & CK & 23.89 & $4.02^{b c}$ & 8.59 & $52.75^{f}$ & 34.17 \\
\hline \multirow[t]{3}{*}{ DO } & LP & 22.20 & $4.32^{\mathrm{ab}}$ & 9.02 & $56.66^{e}$ & 33.11 \\
\hline & $\mathrm{BF}$ & 22.93 & $4.64^{\mathrm{a}}$ & 8.58 & $53.94^{f}$ & 32.58 \\
\hline & CK & 26.01 & $2.78^{e}$ & 6.09 & $62.15^{\mathrm{bc}}$ & 34.12 \\
\hline \multirow[t]{3}{*}{ D7 } & LP & 27.81 & $3.67^{\mathrm{cd}}$ & 6.11 & $61.16^{\mathrm{cd}}$ & 33.28 \\
\hline & $\mathrm{BF}$ & 26.76 & $3.48^{d}$ & 6.10 & $59.01^{d}$ & 33.03 \\
\hline & $\mathrm{CK}$ & 32.04 & $2.35^{\dagger}$ & 5.24 & $64.84^{\mathrm{a}}$ & 36.32 \\
\hline \multirow[t]{2}{*}{ D15 } & LP & 34.05 & $2.30^{f}$ & 5.44 & $65.44^{a}$ & 36.92 \\
\hline & $\mathrm{BF}$ & 32.46 & $3.94^{\mathrm{bc}}$ & 5.42 & $63.77^{\mathrm{ab}}$ & 35.88 \\
\hline SEM & & 4.37 & 0.12 & 0.21 & 0.65 & 0.24 \\
\hline \multicolumn{7}{|c|}{ Significance ( $p$-value) } \\
\hline \multicolumn{2}{|c|}{ Delayed harvest } & $<0.001$ & $<0.001$ & $<0.001$ & $<0.001$ & $<0.001$ \\
\hline \multicolumn{2}{|c|}{ Additive } & 0.581 & $<0.001$ & 0.402 & 0.008 & 0.014 \\
\hline \multicolumn{2}{|l|}{$\begin{array}{l}\text { Delayed } \\
\text { harvest } \times\end{array}$} & 0.762 & $<0.001$ & 0.760 & 0.034 & 0.313 \\
\hline
\end{tabular}

DM, dry matter; Residual WSC, residual water soluble carbohydrates; CP, crude protein; ADF, acid detergent fiber; aNDF, neutral detergent fiber; and SEM, standard of error mean. D0-15 indicated stay-green corn stalks after 0, 7, and 15 days of ear harvest. Different letters within a column are significantly different $(p<0.05)$.

As shown in Table 3, the interaction of delayed harvest and additives significantly affected final $\mathrm{pH}$ and the contents of $\mathrm{NH}_{3}-\mathrm{N}$, lactic acid, acetic acid, and butyric acid $(p<0.05)$, in which delayed harvest had significant effects on all the fermentation indicators in Table $3(p<0.05)$, and additives significantly affected final $\mathrm{pH}$ and the contents of $\mathrm{NH}_{3}-\mathrm{N}$, lactic acid, and acetic acid ( $p<0.001)$. According to Kung et al. (2018), the concentrations of lactic acid and acetic acid were usually negatively correlated to DM content. Our study showed that delayed harvest significantly decreased the lactic acid content $(p<0.001)$, but increased acetic acid content with the increase of DM content $(p<0.001)$. The probable cause was that delayed harvest promoted the metabolism of some acetic acid-producing microbes.

When the DM content of fresh forages was above 30-35\% $\mathrm{DM}$ and induced the rapid production of lactic acid, clostridial fermentation could be minimized because clostridia were intolerant of high osmotic pressure and low $\mathrm{pH}$, thus resulting in a content of low butyric acid (Kung et al., 2018). In our study, the content of butyric acid decreased with the harvest delayed $(p<0.05)$, due to the increase of DM content. Additives significantly reduced the content of butyric acid on D0 and D7 $(p<0.05)$. This might be due to the lower $\mathrm{pH}$ in LP-treated silage and the antibacterial ability of $\mathrm{BF} . \mathrm{NH}_{3}-\mathrm{N}$ is an important indicator for $\mathrm{CP}$ degradation, and its content in well-preserved silage should be lower than $10 \%$ total N (Chen et al., 2020b; Cheng et al., 2021). However, the $\mathrm{NH}_{3}-\mathrm{N}$ content of $\mathrm{CK}$ on each harvest day was higher than that level. The addition of BF and $\mathrm{LP}$ reduced the $\mathrm{NH}_{3}-\mathrm{N}$ content in silages on D0 and D7 compare with the CK samples $(p<0.05)$. Furthermore, the $\mathrm{NH}_{3}-\mathrm{N}$ content of LP-treated silage on D0 and BF-treated silages on D0 and D15 were below $10 \%$ total $\mathrm{N}$, which suggested their low protein proteolysis.

Delayed harvest restricted the reduction of $\mathrm{pH}$ value, which was similar to Wang et al. (2018a), because high DM and low moisture contents in corn stalks after delayed harvest inhibited the silage fermentation. In general, the $\mathrm{pH}$ required for successful ensiling was lower than 4.2. In this study, the $\mathrm{pH}$ in the LP-treated silages was below 4.2, which might indicate that the addition with LP could help inhibit the unfavorable factors produced by the lower fermentation quality due to delayed harvest. Compared with CK samples, the treatment with LP significantly increased the content of lactic acid in silages on D7 and D15 $(p<0.05)$. Therefore, $\mathrm{LAB}$ inoculation might help promote rapid and vigorous fermentation of corn stalks. Studies from Kleinschmit et al. (2005), Teller et al. (2012), and Da Silva et al. (2015) showed that the addition of BF during ensiling had no effect on the concentrations of lactic acid in corn silages. In this study, the BF-treated silage had the highest $\mathrm{pH}$ value and the lowest content of lactic acid $(p<0.05)$, which further confirmed that BF might inhibit the activity or growth of microbial groups, thus reducing the fermentation to acid production. This indicated that good nutrient preservation of LP- or BF-treated silages were attributed to different fermentation qualities. Inoculation of LP during ensiling exerted a good performance in improving silage fermentation, whereas the use of $\mathrm{BF}$ during ensiling reduced $\mathrm{NH}_{3}-\mathrm{N}$ by limiting the microbial fermentation.

\section{Microbial Population of Corn Stalk Silage}

The silage fermentation process is initiated and controlled with microorganisms. As shown in Figure 1, all silages showed a similar microbial composition by plate culture. The counts of yeasts and coliform bacteria only in BF-treated silages were 
TABLE 3 | Final $\mathrm{pH}, \mathrm{NH}_{3}-\mathrm{N}$, and fermentation acids of corn stalk silages treated without (CK) or with LP and BF.

\begin{tabular}{|c|c|c|c|c|c|c|c|}
\hline \multirow{2}{*}{ Delayed harvest } & \multirow{2}{*}{ Additive } & \multirow{2}{*}{ Final pH } & $\mathrm{NH}_{3}-\mathrm{N}$ & \multirow[t]{2}{*}{ Lactic acid } & Acetic acid & Propionic acid & Butyric acid \\
\hline & & & $\%$ total $\mathrm{N}$ & & \multicolumn{3}{|c|}{$\%$ DM } \\
\hline & CK & $3.73^{\ominus}$ & $13.32^{\mathrm{a}}$ & $2.60^{\mathrm{ab}}$ & $0.15^{e}$ & 0.12 & $0.19^{a}$ \\
\hline \multirow[t]{3}{*}{ DO } & LP & $3.70^{e}$ & $8.77^{\circ}$ & $2.79^{a}$ & $0.19^{d e}$ & 0.14 & $0.11^{\mathrm{b}}$ \\
\hline & $\mathrm{BF}$ & $3.89^{d}$ & $8.91^{\circ}$ & $2.70^{a}$ & $0.17^{\mathrm{de}}$ & 0.14 & $0.13^{b}$ \\
\hline & CK & $4.41^{a}$ & $13.41^{a}$ & $1.04^{e}$ & $0.38^{b}$ & 0.05 & $0.13^{b}$ \\
\hline \multirow[t]{3}{*}{ D7 } & LP & $4.11^{\circ}$ & $10.21^{b}$ & $2.40^{b}$ & $0.23^{\circ}$ & 0.07 & $0.01^{c}$ \\
\hline & $\mathrm{BF}$ & $4.31^{\mathrm{ab}}$ & $10.21^{b}$ & $0.96^{e}$ & $0.22^{\mathrm{cd}}$ & 0.06 & $0.01^{c}$ \\
\hline & CK & $4.20^{\mathrm{bc}}$ & $10.80^{b}$ & $1.30^{d}$ & $0.46^{a}$ & 0.14 & $0.01^{c}$ \\
\hline \multirow[t]{2}{*}{ D15 } & LP & $4.18^{\mathrm{bc}}$ & $10.57^{b}$ & $2.06^{c}$ & $0.37^{b}$ & 0.15 & $0.01^{c}$ \\
\hline & $\mathrm{BF}$ & $4.36^{a}$ & $8.94^{c}$ & $1.33^{d}$ & $0.40^{\mathrm{ab}}$ & 0.10 & $0.01^{c}$ \\
\hline SEM & & 0.27 & 0.25 & 0.06 & 0.02 & 0.04 & - \\
\hline \multicolumn{8}{|c|}{ Significance ( $p$-value) } \\
\hline \multicolumn{2}{|l|}{ Delayed harvest } & $<0.001$ & $<0.001$ & $<0.001$ & $<0.001$ & $<0.001$ & 0.007 \\
\hline \multicolumn{2}{|l|}{ Additive } & $<0.001$ & $<0.001$ & $<0.001$ & $<0.001$ & 0.393 & 0.428 \\
\hline \multicolumn{2}{|c|}{ Delayed harvest $\times$ additive } & 0.028 & $<0.001$ & $<0.001$ & $<0.001$ & 0.322 & 0.006 \\
\hline
\end{tabular}

DM, dry matter; $\mathrm{NH}_{3}-\mathrm{N}$, ammonia nitrogen; and SEM, standard of error mean. D0-15 indicated corn stalks after 0,7 , and 15 days of ear harvest. Different letters within a column are significantly different $(p<0.05)$.

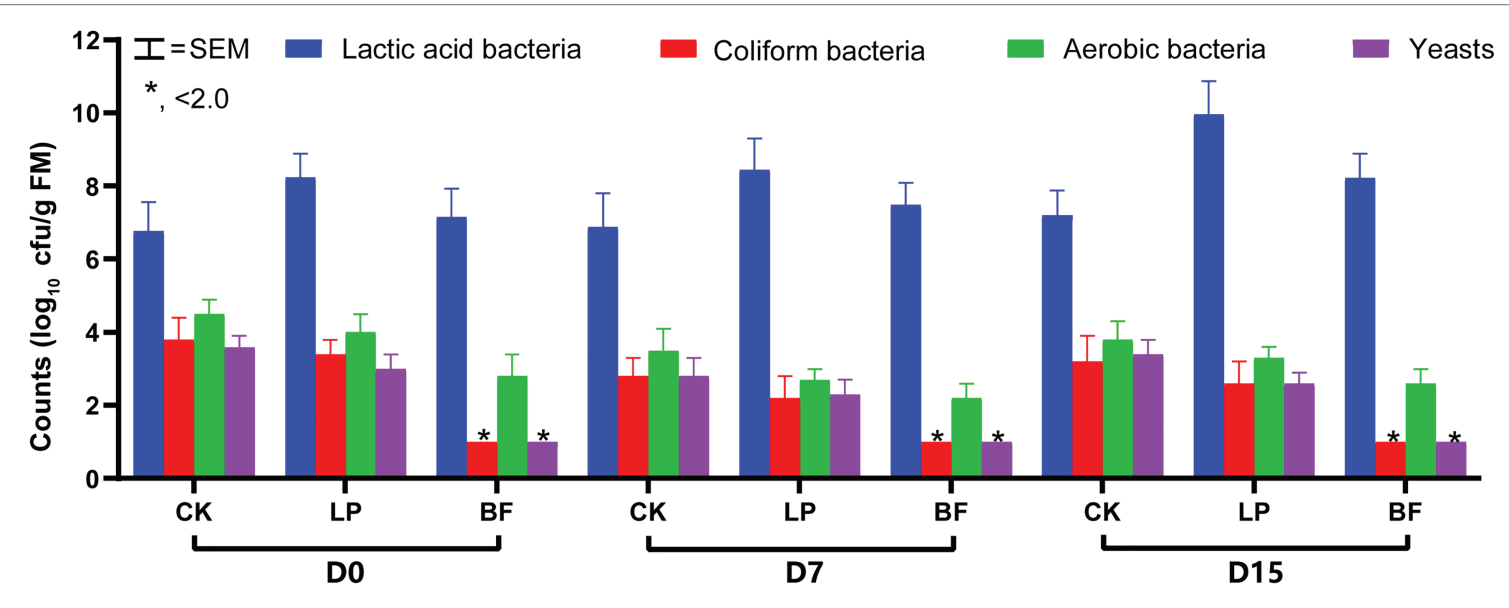

FIGURE 1 | Microbial composition of corn stalk silages treated without (CK) or with L. plantarum and BF. D0, D7, and D15 indicated corn stalks after 0, 7, and 15 days of ear harvest; SEM, standard of error mean; *significance at $p<0.05$.

below the detected level $\left(<2.0 \log _{10} \mathrm{cfu} / \mathrm{g} \mathrm{FM}\right)$. The inhibition of yeasts in BF-treated silages might involve some mechanisms of defect in amino acid uptake, such as the failure of enzymatic systems in the glycolysis and citric acid cycle in yeast cell (Santos et al., 2019). The similar results occurred in grain and corn silages (Knicky and Spörndly, 2011; Morais et al., 2017; Santos et al., 2019). According to Kung et al. (2018), coliform bacteria and yeasts could compete with LAB for fermentation substrates. Our findings indicated that the treatment with BF was useful to inhibit yeasts and coliform bacteria to create the condition where LAB population could grow and propagate quickly.

\section{Bacterial Community Indices of Corn Stalk Silages}

The third generation Pacific Biosciences (PacBio) SMRT improves the classification sensitivity and accuracy of microbial community in silages (Xu et al., 2018). In order to further investigate the bacterial community of corn stalk silage after delayed harvest in South China, SMRT sequencing was used to describe them.

The bacterial alpha diversity of silage samples was shown in Table 4. The PE reads of each sample ranged from 5,847 to 6,693 , and the total number of observed species was 875 . The delayed harvest, additives and their interactions significantly affected the bacterial richness (Chao 1 and ACE) and the diversity (Shannon and PD whole tree; $p<0.05$ ). Compared with CK samples, additives increased Chao 1, ACE, Shannon, and PD whole tree of silages on D0 $(p<0.05)$. However, the reverse trend was observed in silages at D7 and D15. This might be due to the fact that the use of additives enhanced the superiority of dominant bacteria and subsequently reduced the richness and diversity of other bacteria in silages with a high DM (Ni et al., 2017a). Especially, the treatment with LP had the lowest Shannon and PD whole tree in silages on D7 and D15 ( $p<0.05)$. According to Kung et al. (2003) and 
TABLE 4 | Bacterial alpha-diversity of corn stalk silages treated without (CK) or with L. plantarum and BF.

\begin{tabular}{|c|c|c|c|c|c|c|c|}
\hline Delayed harvest & Additive & $\mathrm{PE}$ reads & Observed species & Shannon & Chao 1 & ACE & PD whole tree \\
\hline & CK & 6,050 & $110^{\mathrm{bc}}$ & $2.27^{b}$ & $214.00^{d}$ & $239.01^{d}$ & $8.67^{\mathrm{cd}}$ \\
\hline \multirow[t]{3}{*}{ DO } & LP & 6,043 & $221^{a}$ & $2.76^{a}$ & $492.73^{b}$ & $594.48^{b}$ & $12.94^{\mathrm{a}}$ \\
\hline & $\mathrm{BF}$ & 6,185 & $157^{\mathrm{ab}}$ & $2.76^{a}$ & $323.83^{c}$ & $397.76^{c}$ & $10.58^{b}$ \\
\hline & CK & 6,428 & $134^{b}$ & $1.76^{\circ}$ & $576.85^{a}$ & $747.02^{\mathrm{a}}$ & $9.73^{b c}$ \\
\hline \multirow[t]{3}{*}{ D7 } & LP & 5,847 & $37^{c}$ & $0.91^{e}$ & $51.87^{f}$ & $55.06^{f}$ & $4.95^{\mathrm{fg}}$ \\
\hline & $\mathrm{BF}$ & 6,165 & $86^{b c}$ & $1.21^{d}$ & $130.29^{e}$ & $150.80^{e}$ & $8.27^{d}$ \\
\hline & CK & 6,390 & $55^{\mathrm{c}}$ & $2.26^{b}$ & $64.30^{f}$ & $68.71^{f}$ & $6.36^{e}$ \\
\hline \multirow[t]{2}{*}{ D15 } & LP & 6,693 & $30^{c}$ & $1.16^{d}$ & $37.76^{f}$ & $38.23^{f}$ & $4.39^{9}$ \\
\hline & $\mathrm{BF}$ & 6,049 & $45^{c}$ & $1.88^{c}$ & $54.22^{f}$ & $58.76^{f}$ & $6.01^{\text {ef }}$ \\
\hline SEM & & 257 & 9 & 0.09 & 26.58 & 34.06 & 0.39 \\
\hline \multicolumn{8}{|c|}{ Significance ( $p$-value) } \\
\hline \multicolumn{2}{|l|}{ Delayed harvest } & 0.327 & $<0.001$ & $<0.001$ & $<0.001$ & $<0.001$ & $<0.001$ \\
\hline \multicolumn{2}{|l|}{ Additive } & 0.720 & 0.704 & $<0.001$ & $<0.001$ & $<0.001$ & 0.031 \\
\hline \multicolumn{2}{|c|}{ Delayed harvest $x$ additive } & 0.443 & $<0.001$ & $<0.001$ & $<0.001$ & $<0.001$ & $<0.001$ \\
\hline
\end{tabular}

SEM, standard of error mean. D0-15 indicated stay-green corn stalks after 0, 7, and 15 days of ear harvest. Different letters within a column are significantly different ( $p<0.05)$.

Oliveira et al. (2017), the inoculation with exogenous LAB generally had a positive effect on sufficient lactic acid production and inhibited the activity of other harmful bacteria during the fermentation process. The findings of our study might confirm that exogenous L. plantarum exhibited high competitiveness for dominance during silage fermentation of corn stalks. Therefore, it is necessary to investigate the dominated species of bacterial community of corn stalks.

As shown in Figure 2, PCoA revealed that component 1 and component 2 could explain 68.84 and $10.59 \%$ of the total variance in bacterial community structure, respectively. Silage samples were well separated between D0, D7, and D15, which suggested that bacterial community would be affected by harvest time of corn stalks. Report from Ni et al. (2017b) showed that the variation of microbial community might explain the differences of silage quality. The findings of our study revealed that additives increased the dissimilarity in bacterial community in silage samples on D7 and D15, suggesting that the treatment with LP and BF could markedly shift the bacterial community composition and construction.

The relative abundance of the top 10 bacterial species in corn stalk silage was shown in Figure 3. Lactobacillus plantarum and Lactobacillus brevis were the dominant species in corn stalk silages. With the delayed harvest, the abundance of L. plantarum increased, while the abundance of $L$. brevis decreased. It is generally recognized that L. plantarum is often used as an inoculant to promote silage fermentation (Yan et al., 2019). However, the increased dominance of $L$. plantarum was not effective in enhancing the content of lactic acid with the delayed harvest, because the low moisture content inhibited the activity of most microorganisms, and dominant L. plantarum showed a high survival competitiveness but a limited fermentation capacity on inferior condition. Compared with CK samples, the abundance of L. brevis was lower, while the abundance of L. plantarum was higher in additive-treated silage on D15, which indicated that additives could promote the dominance of L. plantarum in silage with a high DM. Weissella is abundant in fresh materials and tended to be dominated in the early ensiling period, while they will be replaced by more acid-tolerant Lactobacillus in the late ensiling period (Graf et al., 2016; Pereira et al., 2019).

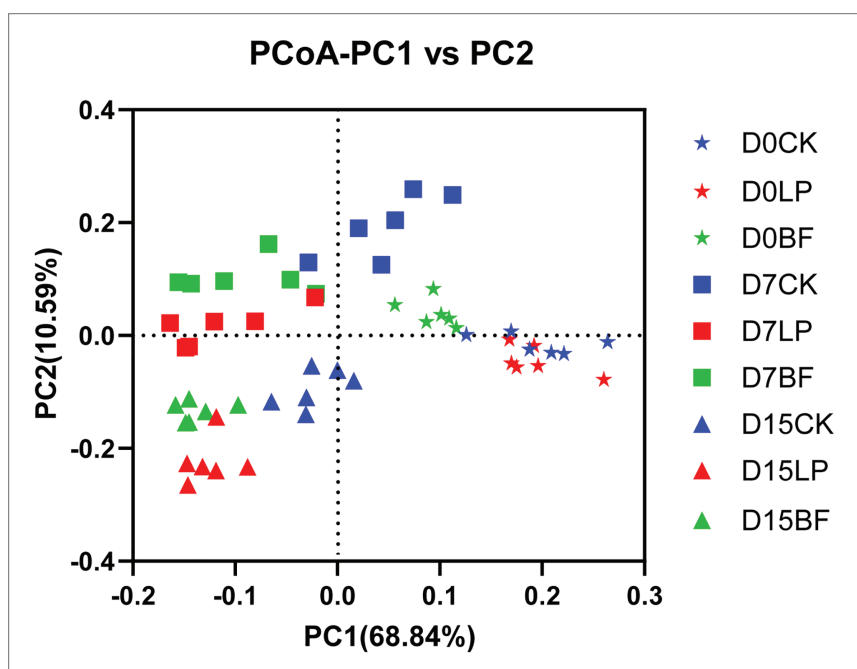

FIGURE 2 | Principal coordinates analysis (PCoA) analysis of bacterial community structure of corn stalk silages treated without $(\mathrm{CK})$ or with L. plantarum and BF. D0, D7, and D15 indicated stay-green corn stalks after 0,7 , and 15 days of ear harvest.

In our study, the high abundance of Weissella paramesenteroides in $\mathrm{CK}$ and $\mathrm{BF}$ treatment of silages on D7 might be due to the slow fermentation process, resulting in a lower abundance of L. plantarum. Furthermore, Lactobacillus ginsenosidimutans and Lactobacillus spicheri could be isolated from fermented food, and sometimes used as probiotic strains for improvement of functional foods (Gautam and Sharma, 2015; Chiş et al., 2020). However, their effects on silages should be further studied.

\section{Correlation Between Silage Parameters and Bacterial Community}

The spearman analysis between silage parameters and bacterial species was shown in Figure 4. The results showed that residual WSC was negatively correlated to L. plantarum $(p<0.05)$, which confirmed that WSC was a determinant substrate for L. plantarum in silage fermentation (Chen et al., 2020b). 


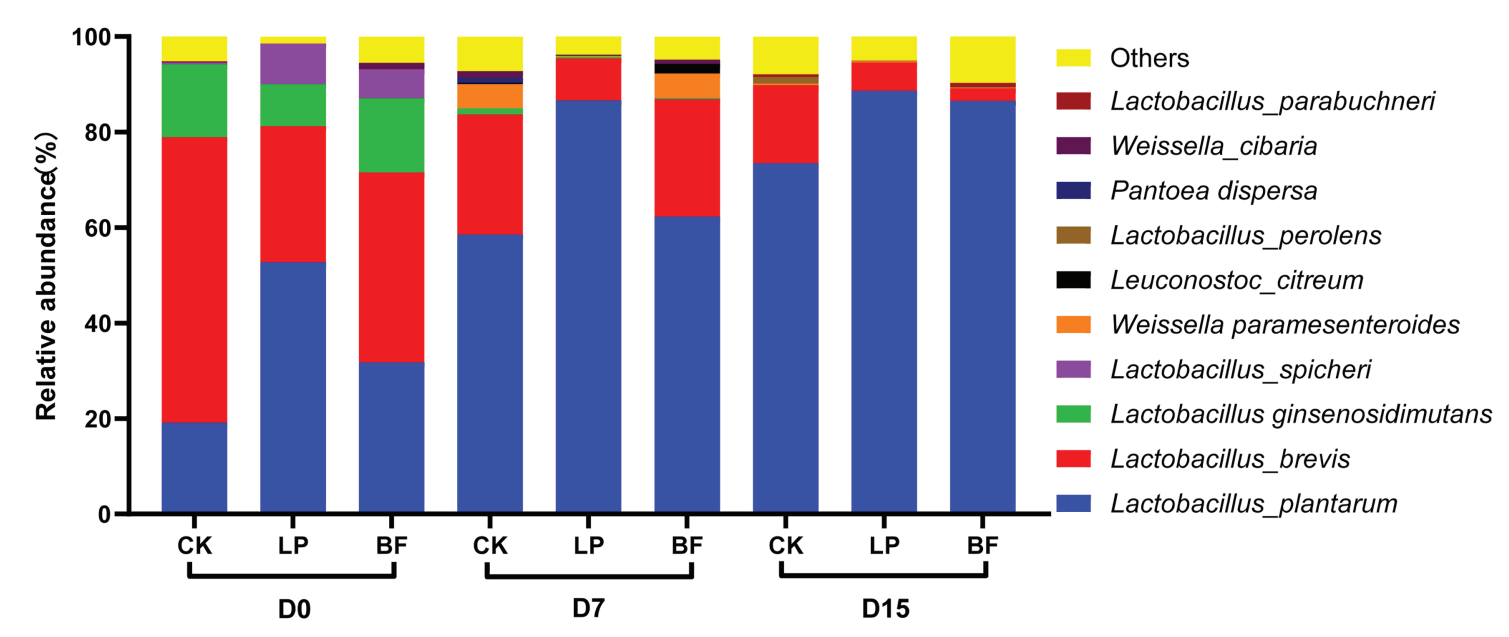

FIGURE 3 | Relative abundance of top 10 bacterial species in corn stalk silages treated without (CK) or with L. plantarum and BF. D0, D7, and D15 indicated corn stalks after 0,7 , and 15 days of ear harvest.

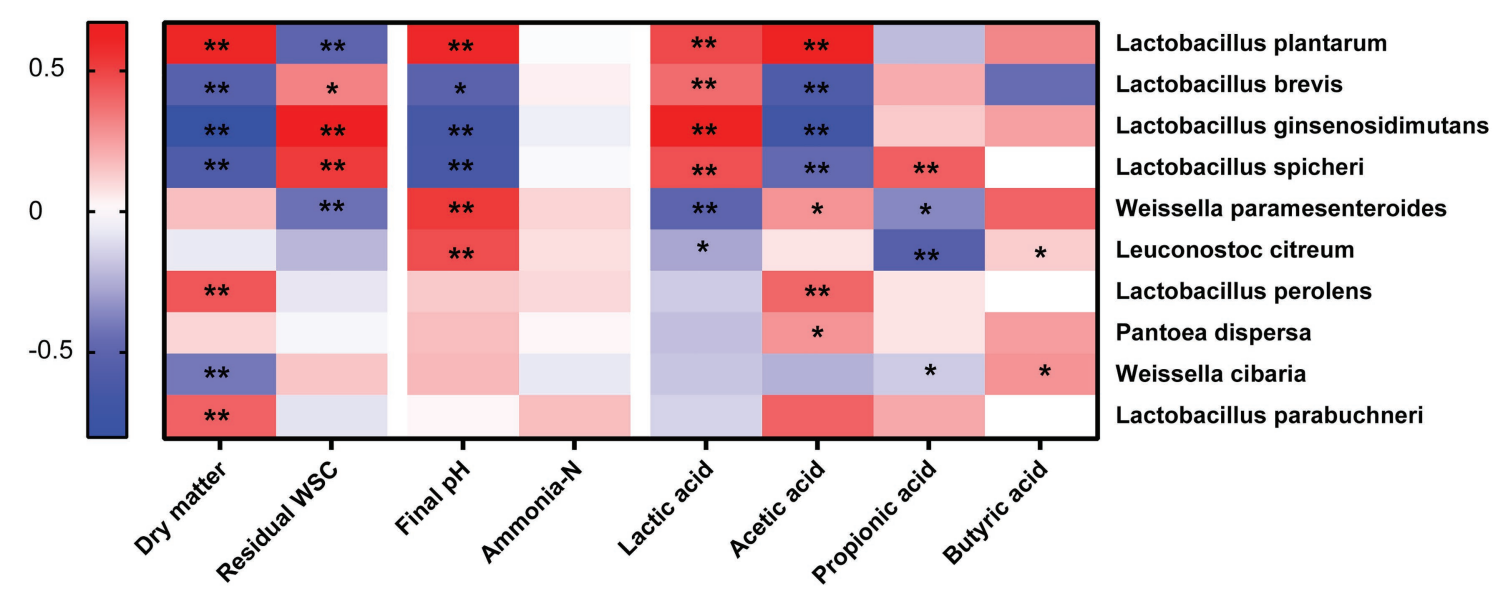

FIGURE 4 | Spearman analysis between silage parameters and bacterial species. *significance at $p<0.05$; **significance at $p<0.01$.

Lactobacillus exerted a significant effect in increasing lactic acid and reducing $\mathrm{pH}$ in the later stage (Cai et al., 1998). Therefore, our study showed that lactic acid was positively correlated to some Lactobacillus genera (L. plantarum, L. ginsenosidimutans, and L. spicheri; $p<0.05$ ). It was generally recognized that $L$. plantarum was the dominant homofermentative bacteria for increasing lactic acid and decreasing $\mathrm{pH}$ in silage fermentation. However, the final $\mathrm{pH}$ and acetic acid were positively correlated to L. plantarum $(p<0.05)$. In addition, the dry matter content was also positively correlated to $L$. plantarum in this study $(p<0.05)$. These were consistent with the results of silage quality and bacterial community of corn stalk silage after the delayed harvest, that is, the DM content and $L$. plantarum abundance increased, while the lactic acid content decreased, and the acetic acid content enhanced. The similar results were also reported by $\mathrm{Ni}$ et al. (2017a), who found that the lactic acid/acetic acid was lower in samples with a high DM compared with that in soybean silage samples with a low DM. That might because the high DM content was more likely cause the metabolism of heterofermentative L. plantarum, but more studies should be further conducted.

\section{CONCLUSION}

Delayed harvest could restrict lactic acid fermentation, and increase acetic acid production and $\mathrm{pH}$ value in corn stalk silage. $\mathrm{LP}$ and $\mathrm{BF}$ additives have an ability of improving the fermentation quality of corn stalk silage through decreasing butyric acid and $\mathrm{NH}_{3}-\mathrm{N}$ contents. In addition, SMRT result showed that LP and BF could enhance fermentation quality of delayed harvest corn stalk by shifting bacterial community. Overall, our research confirmed that inoculated with LP or $\mathrm{BF}$ could be feasible ways for improving the delayed harvest corn stalk silage. 
DATA AVAILABILITY STATEMENT

The datasets generated for this study can be found in Sequence Read Archive (SRA), http://www.ncbi.nlm.nih.gov/ sra/, PRJNA718962.

\section{AUTHOR CONTRIBUTIONS}

LG, YL, PL, LC, and WG designed the study and wrote the manuscript. PL and LC performed the experiments. LG and PL conducted the statistical and bioinformatics analysis. PL

\section{REFERENCES}

Alli, I., Pabari, S., Fairbairn, R., and Baker, B. E. (1985). The effects of sorbates on the ensilage of chopped whole-plant maize and lucerne. J. Sci. Food Agric. 36, 63-70. doi: 10.1002/jsfa.2740360202

AOAC (1990). Official Methods of Analysis. Association of Official Analytical Chemists. Arlington, VA: Association of Official Analytical Chemists.

Bekavac, G., Stojaković, M., Jocković, D., Boćanski, J., and Purar, B. (1998). Path analysis of stay-green trait in maize. Cereal Res. Commun. 26, 161-167. doi: $10.1007 /$ BF03543483

Broderick, G. A., and Kang, J. H. (1980). Automated simultaneous determination of ammonia and total amino acids in ruminal fluid and in vitro media. $J$. Dairy Sci. 63, 64-75. doi: 10.3168/jds.S0022-0302(80)82888-8

Cai, Y. M., Benno, Y., Ogawa, M., and Kumai, S. (1999). Effect of applying lactic acid bacteria isolated from forage crops on fermentation characteristics and aerobic deterioration of silage. J. Dairy Sci. 82, 520-526. doi: 10.3168/ jds.S0022-0302(99)75263-X

Cai, Y. M., Benno, Y., Ogawa, M., Ohmomo, S., Kumai, S., and Nakase, T. (1998). Influence of lactobacillus spp. from an inoculant and of Weissella and Leuconostoc spp. from forage crops on silage fermentation. Appl. Environ. Microbiol. 64, 2982-2987. doi: 10.1128/AEM.64.8.2982-2987.1998

Cai, Y., Du, Z., Yamasaki, S., Nguluve, D., Tinga, B., Macome, F., et al. (2020). Influence of microbial additive on microbial populations, ensiling characteristics, and spoilage loss of delayed sealing silage of Napier grass. Asian-Australas. J. Anim. Sci. 33, 1103-1112. doi: 10.5713/ajas.19.0471

Chen, L., Li, P., Gou, W., You, M., Cheng, Q., Bai, S., et al. (2020a). Effects of inoculants on the fermentation characteristics and in vitro digestibility of reed canary grass (Phalaris arundinacea L.) silage on the Qinghai-Tibetan plateau. Anim. Sci. J. 91:e13364. doi: 10.1111/asj.13364

Chen, L., Qu, H., Bai, S., Yan, L., You, M., Gou, W., et al. (2020b). Effect of wet sea buckthorn pomace utilized as an additive on silage fermentation profile and bacterial community composition of alfalfa. Bioresour. Technol. 314:123773. doi: 10.1016/j.biortech.2020.123773

Cheng, Q., Li, P., Xiao, B., Yang, F., Li, D., Ge, G., et al. (2021). Effects of $\mathrm{LAB}$ inoculant and cellulase on the fermentation quality and chemical composition of forage soybean silage prepared with corn Stover. Grassl. Sci. 67, 83-90. doi: $10.1111 /$ grs. 12289

Chiş, M. S., Păucean, A., Man, S. M., Mureşan, V., Socaci, S. A., Pop, A., et al. (2020). Textural and sensory features changes of gluten free muffins based on rice sourdough fermented with Lactobacillus spicheri DSM 15429. Foods 9:363. doi: 10.3390/foods9030363

Christian, Q., Elmar, P., Pelin, Y., Jan, J., Timmy, S., Pablo, Y., et al. (2013). The SILVA ribosomal RNA gene database project: improved data processing and web-based tools. Nucleic Acids Res. 41, D590-D596. doi: 10.1093/nar/ gks1219

Da Silva, T. C., Smith, M. L., Barnard, A. M., and Kung, L. (2015). The effect of a chemical additive on the fermentation and aerobic stability of high-moisture corn. J. Dairy Sci. 98, 8904-8912. doi: 10.3168/jds. 2015-9640

Du, Z., Sun, L., Chen, C., Lin, J., Yang, F., and Cai, Y. (2021). Exploring microbial community structure and metabolic gene clusters during silage fermentation of paper mulberry, a high-protein woody plant. Anim. Feed Sci. Technol. 275:114766. doi: 10.1016/j.anifeedsci.2020.114766 and $\mathrm{CZ}$ were involved in the revision of the manuscript. All authors contributed to the article and approved the submitted version.

\section{FUNDING}

This work was supported by funds from Sichuan Program for Key Research and Development (18ZDYF1385) and Guizhou Talent Base of Grassland Ecological Animal Husbandry (RCJD2018-13).

Edgar, R. C. (2004). MUSCLE: a multiple sequence alignment method with reduced time and space complexity. BMC Bioinformatics 5:113. doi: 10.1186/1471-2105-5-113

Edgar, R. C. (2013). UPARSE: highly accurate OTU sequences from microbial amplicon reads. Nat. Methods. 10, 996-998. doi: 10.1038/nmeth.2604

Edgar, R. C., Haas, B. J., Clemente, J. C., Quince, C., and Knight, R. (2011). UCHIME improves sensitivity and speed of chimera detection. Bioinformatics 27, 2194-2200. doi: 10.1093/bioinformatics/btr381

Gautam, N., and Sharma, N. (2015). Evaluation of probiotic potential of new bacterial strain, Lactobacillus spicheri G2 isolated from gundruk. Proc. Natl. Acad. Sci. India B Biol. Sci. 85, 979-986. doi: 10.1007/ s40011-014-0458-9

Graf, K., Ulrich, A., Idler, C., and Klocke, M. (2016). Bacterial community dynamics during ensiling of perennial ryegrass at two compaction levels monitored by terminal restriction fragment length polymorphism. J. Appl. Microbiol. 120, 1479-1491. doi: 10.1111/jam.13114

Guo, G., Shen, C., Liu, Q., Zhang, S., Shao, T., Wang, C., et al. (2020a). The effect of lactic acid bacteria inoculums on in vitro rumen fermentation, methane production, ruminal cellulolytic bacteria populations and cellulase activities of corn Stover silage. J. Integr. Agric. 19, 838-847. doi: 10.1016/ S2095-3119(19)62707-3

Guo, G., Shen, C., Liu, Q., Zhang, S. L., Wang, C., Chen, L., et al. (2019). Fermentation quality and in vitro digestibility of first and second cut alfalfa (Medicago sativa L.) silages harvested at three stages of maturity. Anim. Feed Sci. Technol. 257:114274. doi: 10.1016/j.anifeedsci.2019.114274

Guo, L., Yao, D., Li, D., Lin, Y., Bureenok, S., Ni, K., et al. (2020b). Effects of lactic acid bacteria isolated from rumen fluid and feces of dairy cows on fermentation quality, microbial community, and in vitro digestibility of alfalfa silage. Front. Microbiol. 10:2998. doi: 10.3389/fmicb.2019.02998

Haas, B. J., Gevers, D., Earl, A. M., Feldgarden, M., Ward, D. V., Giannoukos, G., et al. (2011). Chimeric 16S rRNA sequence formation and detection in Sanger and 454-pyrosequenced PCR amplicons. Genome Res. 21, 494-504. doi: $10.1101 /$ gr.112730.110

Keshri, J., Chen, Y., Pinto, R., Kroupitski, Y., Weinberg, Z. G., and Sela, S. S. (2019). Bacterial dynamics of wheat silage. Front. Microbiol. 10:1532. doi: 10.3389/fmicb.2019.01532

Kleinschmit, D. H., Schmidt, R. J., and Kung, L. (2005). The effects of various antifungal additives on the fermentation and aerobic stability of corn silage. J. Dairy Sci. 88, 2130-2139. doi: 10.3168/jds.S0022-0302(05)72889-7

Knicky, M., and Spörndly, R. (2011). The ensiling capability of a mixture of sodium benzoate, potassium sorbate, and sodium nitrite. J. Dairy Sci. 94, 824-831. doi: 10.3168/jds.2010-3364

Kung, L., Martin, R. S., and Lin, C. J. (2003). "Silage additives," in Silage Science and Technology. eds. D. R. Buxton, R. E. Muck and J. H. Harrison (Madison, WI, USA: American Society of Agronomy, Crop Science Society of America, Soil Science Society of America), 305-360.

Kung, L., Shaver, R. D., Grant, R. J., and Schmidt, R. J. (2018). Silage review: interpretation of chemical, microbial, and organoleptic components of silages. J. Dairy Sci. 101, 4020-4033. doi: 10.3168/jds.2017-13909

Li, J., Zhang, R., Siddhu, M. A. H., He, Y., Wang, W., Li, Y., et al. (2015). Enhancing methane production of corn Stover through a novel way: sequent pretreatment of potassium hydroxide and steam explosion. Bioresour. Technol. 181, 345-350. doi: 10.1016/j.biortech.2015.01.050 
Li, M., Zhang, L., Zhang, Q., Zi, X., Lv, R., Tang, J., et al. (2020). Impacts of citric acid and malic acid on fermentation quality and bacterial community of cassava foliage silage. Front. Microbiol. 11:595622. doi: 10.3389/ fmicb.2020.595622

Morais, G., Daniel, J. L. P., Kleinshmitt, C., Carvalho, P. A., Fernandes, J., and Nussio, L. G. (2017). Additives for grain silages: a review. Slovak J. Anim. Sci. 20, 42-54.

Muck, R. E., Nadeau, E. M. G., Mcallister, T. A., Contreras-Govea, F. E., Santos, M. C., and Kung, L. (2018). Silage review: recent advances and future uses of silage additives. J. Dairy Sci. 101, 3980-4000. doi: 10.3168/ jds.2017-13839

Murphy, R. P. (1958). A method for the extraction of plant samples and the determination of total soluble carbohydrates. J. Sci. Food Agric. 9, 714-717. doi: $10.1002 /$ jsfa.2740091104

Ni, K., Minh, T. T., Tu, T. T. M., Tsuruta, T., Pang, H., and Nishino, N. (2017b). Comparative microbiota assessment of wilted Italian ryegrass, whole crop corn, and wilted alfalfa silage using denaturing gradient gel electrophoresis and next-generation sequencing. Appl. Microbiol. Biotechnol. 101, 1385-1394. doi: 10.1007/s00253-016-7900-2

Ni, K., Wang, F., Zhu, B., Yang, J., Zhou, G., Pan, Y., et al. (2017a). Effects of lactic acid bacteria and molasses additives on the microbial community and fermentation quality of soybean silage. Bioresour. Technol. 238, 706-715. doi: 10.1016/j.biortech.2017.04.055

Oliveira, A. S., Weinberg, Z. G., Ogunade, I. M., Cervantes, A. A. P., Arriola, K. G., Jiang, Y., et al. (2017). Meta-analysis of effects of inoculation with homofermentative and facultative heterofermentative lactic acid bacteria on silage fermentation, aerobic stability, and the performance of dairy cows. J. Dairy Sci. 100, 4587-4603. doi: 10.3168/jds.2016-11815

Pereira, G. A., Santos, E. M., Araújo, G. G. L., Oliveira, J. S., Pinho, R. M. A., Zanine, A. D. M., et al. (2019). Isolation and identification of lactic acid bacteria in fresh plants and in silage from Opuntia and their effects on the fermentation and aerobic stability of silage. J. Agric. Sci. 157, 684-692. doi: 10.1017/S0021859620000143

Qiong, W., George, M. G., James, M. T., and James, R. C. (2007). Naive Bayesian classifier for rapid assignment of rRNA sequences into the new bacterial taxonomy. Appl. Environ. Microb. 73, 5261-5267. doi: 10.1128/ AEM.00062-07

Queiroz, O. C. M., Ogunade, I. M., Weinberg, Z., and Adesogan, A. T. (2018). Silage review: foodborne pathogens in silage and their mitigation by silage additives. J. Dairy Sci. 101, 4132-4142. doi: 10.3168/jds.2017-13901

Santos, W. P., Salvati, G. G. S., Arthur, B. A. V., Daniel, J. L. P., and Nussio, L. G. (2019). The effect of sodium benzoate on the nutritive value of rehydrated sorghum grain silage for dairy cows. Anim. Feed Sci. Technol. 256:114267. doi: 10.1016/j.anifeedsci.2019.114267

Sikora, M. C., Hatfield, R. D., and Kalscheur, K. F. (2019). Fermentation and chemical composition of high-moisture lucerne leaf and stem silages harvested at different stages of development using a leaf stripper. Grass Forage Sci. 74, 254-263. doi: 10.1111/gfs.12423

Teller, R. S., Schmidt, R. J., Whitlow, L. W., and Kung, L. (2012). Effect of physical damage to ears of corn before harvest and treatment with various additives on the concentration of mycotoxins, silage fermentation, and aerobic stability of corn silage. J. Dairy Sci. 95, 1428-1436. doi: 10.3168/ jds.2011-4610
Thomas, H., and Smart, C. M. (1993). Crops that stay green. Ann. Appl. Biol. 123, 193-219. doi: 10.1111/j.1744-7348.1993.tb04086.x

Tian, J., Li, Z., Yu, Z., Zhang, Q., and Li, X. (2017). Interactive effect of inoculant and dried jujube powder on the fermentation quality and nitrogen fraction of alfalfa silage. Anim. Sci. J. 88, 633-642. doi: 10.1111/asj.12689

Van Soest, P. V., Robertson, J. B., and Lewis, B. A. (1991). Methods for dietary fiber, neutral detergent fiber, and nonstarch polysaccharides in relation to animal nutrition. J. Dairy Sci. 74, 3583-3597. doi: 10.3168/jds.S0022-0302 (91)78551-2

Wang, H., Guan, H., Chen, M., Peng, A., Liu, M., Li, C., et al. (2018a). Effect of different harvesting periods on grain yield and stalk silage quality of maize. Pratacult. Sci. 35, 1574-1581. doi: 10.11829/j.issn.1001-0629.2017-0410

Wang, Y., Wang, C., Zhou, W., Yang, F. Y., Chen, X. Y., and Zhang, Q. (2018b). Effects of wilting and Lactobacillus plantarum addition on the fermentation quality and microbial community of Moringa oleifera leaf silage. Front. Microbiol. 9:1817. doi: 10.3389/fmicb.2018.01817

Xu, D., Ding, W., Ke, W., Li, F., Zhang, P., and Guo, X. (2018). Modulation of metabolome and bacterial community in whole crop corn silage by inoculating homofermentative Lactobacillus plantarum and heterofermentative Lactobacillus buchneri. Front. Microbiol. 9:3299. doi: 10.3389/fmicb.2018.03299

Yan, Y., Li, X., Guan, H., Huang, L., Ma, X., Peng, Y., et al. (2019). Microbial community and fermentation characteristic of Italian ryegrass silage prepared with corn Stover and lactic acid bacteria. Bioresour. Technol. 279, 166-173. doi: 10.1016/j.biortech.2019.01.107

Yari, M., Valizadeh, R., Naserian, A. A., Ghorbani, G. R., Moghaddam, P. R., Jonker, A., et al. (2012). Botanical traits, protein and carbohydrate fractions, ruminal degradability and energy contents of alfalfa hay harvested at three stages of maturity and in the afternoon and morning. Anim. Feed Sci. Technol. 172, 162-170. doi: 10.1016/j.anifeedsci.2012.01.004

Zhang, G., Li, Y., Fang, X., Cai, Y., and Zhang, Y. (2020a). Lactation performance, nitrogen utilization, and profitability in dairy cows fed fermented total mixed ration containing wet corn gluten feed and corn Stover in combination replacing a portion of alfalfa hay. Anim. Feed Sci. Technol. 269:114687. doi: 10.1016/j.anifeedsci.2020.114687

Zhang, Y., Liu, Y., Meng, Q., Zhou, Z., and Wu, H. (2020b). A mixture of potassium sorbate and sodium benzoate improved fermentation quality of whole-plant corn silage by shifting bacterial communities. J. Appl. Microbiol. 128, 1312-1323. doi: 10.1111/jam.14571

Zhang, X. L., Wang, Q., Zhao, Y. L., Yang, Q. H., and Li, C. H. (2010). Effects of nitrogen fertilization rate and harvest time on summer maize grain yield and its quality. J. Appl. Ecol. 21, 2565-2572. doi: 10.13287/j.1001-9332.2010.0372

Conflict of Interest: The authors declare that the research was conducted in the absence of any commercial or financial relationships that could be construed as a potential conflict of interest.

Copyright (c) 2021 Guo, Lu, Li, Chen, Gou and Zhang. This is an open-access article distributed under the terms of the Creative Commons Attribution License (CC BY). The use, distribution or reproduction in other forums is permitted, provided the original author(s) and the copyright owner(s) are credited and that the original publication in this journal is cited, in accordance with accepted academic practice. No use, distribution or reproduction is permitted which does not comply with these terms. 